Article

CORREIA, N.M. ${ }^{1 *}$

CARVALHO, A.D.F. ${ }^{1}$

\section{Selectivity of LinURON HeRbicide for CaRRot When SPRAYEd IN POST-EMERGENCE}

\author{
Seletividade do Herbicida Linuron para Cenoura Quando Pulverizado em \\ Pós-Emergência
}

\section{* Corresponding author: \\ <nubia.correia@embrapa.br>}

Received: May 3, 2016

Approved: June 8, 2016

Planta Daninha 2017; v35:e017161461
ABSTRACT - Among the herbicides registered for carrot crop in Brazil, linuron is the most used one, according to horticulturists. However, there are few reports in the literature on its selectivity for the carrot plants. Therefore, the aim of this work is to study the selectivity of linuron herbicide for growing carrots, influenced by genotype, product dosing, and plant development phase at the time of application. This work included four experiments, one in greenhouse, and three in the field, in area of commercial carrot production. In the greenhouse, the experimental design was completely randomized in factorial scheme $4 \times 2 \times 3$, with four replications. Linuron, at doses $0,225,450$ and $675 \mathrm{~g}$ a.i. ha ${ }^{-1}$ was sprayed in plants with 1 and 2-3 true leaves of cultivars Brasilia, Kuronan and Verano. In the field, two experiments were carried out, one with the cultivar Verano and the other with BRS Planalto. In three experiments, the experimental design was a randomized block in factorial $2 \times 5$, with four replications. Verano or BRS Planalto plants were sprayed, in two stages of development (1 and 3 true leaves for Verano, and 1 and 2 true leaves for BRS Planalto), with 0, 225, 450, 675 and $990 \mathrm{~g}$ a.i. ha ${ }^{-1}$ of linuron. Post-emergence herbicide linuron was selective for growing carrots, regardless of cultivar, product dosage and plant development stage at the time of application.

Keywords: phytointoxication, Daucus carota, tolerance.

RESUMO - Entre os herbicidas registrados para a cultura da cenoura no Brasil, o linuron é o mais utilizado, segundo informações dos horticultores. Entretanto, há poucos relatos na literatura sobre a sua seletividade para as plantas de cenoura. Por isso, objetivou-se aqui estudar a seletividade do herbicida linuron para a cultura da cenoura, influenciada por genótipo, dosagem do produto e estádio de desenvolvimento das plantas no momento da aplicação. O trabalho englobou a realização de quatro experimentos, um em casa de vegetação e três em campo, em área de produção comercial de cenoura. Em casa de vegetação, o delineamento experimental foi o inteiramente casualizado, em esquema fatorial $4 \times 2 \times 3$, com quatro repetições. O linuron, nas dosagens de 0, 225, 450 e $675 \mathrm{~g}$ i.a. $\mathrm{ha}^{-1}$, foi pulverizado em plantas com 1 e 2-3 folhas verdadeiras dos cultivares Brasilia, Kuronan e Verano. Em campo, foram instalados dois experimentos com o cultivar Verano e outro com o BRS Planalto. Nos três experimentos, o delineamento experimental foi o de blocos ao acaso, em esquema fatorial $2 \times 5$, com quatro repetições. As plantas de Verano ou BRS Planalto, em dois estádios de desenvolvimento (1 e 3 folhas verdadeiras para Verano e 1 e 2 folhas verdadeiras para BRS Planalto), foram pulverizadas com 0, 225, 450, 675 e $990 \mathrm{~g}$ i.a. $\mathrm{ha}^{-1}$ de

1 Embrapa Vegetables, Brasilia-DF, Brazil. 
linuron. O herbicida linuron, pulverizado em pós-emergência, foi seletivo para a cultura da cenoura, independentemente de cultivar, dosagem do produto e estádio de desenvolvimento das plantas no momento da aplicação.

Palavras-chave: fitointoxicação, Daucus carota, tolerância.

\section{INTRODUCTION}

Carrot is among the five main vegetables grown in Brazil. It is estimated that the annual output is 750 ton, approximately 25,000 hectares (Anuário..., 2015). Among the various biotic factors responsible for decline in the quantity and quality of roots, has to do with weed interference. The losses in production of roots can reach up 100\%, if not appropriately controlled (Zagonel et al., 1999; Coelho et al., 2009; Freitas et al., 2009; Swanton et al., 2010). The values vary according to the time when interference occurs, its duration, type and density of weeds, weather conditions, among others. In addition to the reduction in the quantity and quality of the product, the weeds can serve as an alternative to pest host, diseases and nematodes (Alvarez and Hutchinson, 2005; Boydston et al., 2008).

The management of the weed community in carrot culture, therefore, is paramount. Among the control methods employed, the use of chemical products is the most widely used. However, the choice of chemical treatment (herbicide, product associations, dosage or time of application) should also consider its selectivity for the culture of commercial interest. Selectivity is the characteristic of the herbicides that enables your application to control weeds without damaging the crops. In general, selectivity is the result of differences in the response of the species to a particular herbicide and depends upon many interrelated factors (Alterman and Jones, 2003). Selectivity is not only assigned to a herbicide, but also to the applied dose and the plant development stage. Soil, climate and the use of adjuvant may also alter the degree of selectivity and in some cases, the sensitivity varies depending on the genetic material (Alterman and Jones, 2003).

Among the herbicides registered for carrot crop in Brazil, linuron is the most used one, according to horticulturists. However, there are few reports in the literature on its selectivity for the cultivation of carrot (Bellinder et al., 1997; Jensen et al., 2004; Williams II and Boydston, 2005; Main et al, 2013; Pacanoski et al, 2014; Gruszecki et al, 2015), and none of them was developed in Brazilian conditions.

Linuron hinders electron transport in photosystem II in the photochemical step in photosynthesis. It belongs to the chemical group of substituted ureas and is registered for the control of eudicotyledon weeds in carrot culture in dosages $720-990 \mathrm{~g}$ a.i. ha ${ }^{-1}$, depending on soil texture (Rodrigues and Almeida, 2011). Most areas of commercial carrot production work with lower doses (around $225 \mathrm{~g}$ a.i. $\mathrm{ha}^{-1}$ ) sprayed two to three times until the close of the crop canopy. On such doses, linuron has short residual effect in the soil, acting basically on post-emergence, not inhibiting new emergence weed flows. The use of subdoses is made because there is the concern of technicians that higher dosages of herbicide can affect the amount or quality of carrot roots.

This works has been carried out taking into account the hypothesis that linuron herbicide, in doses registered for this culture, is selective for carrot plants, regardless of genetic material and plant development stage. Thus, the objective of this work was to study the selectivity of the herbicide linuron for carrot, influenced by genotype, product dosing, and plant development stage at the time of application.

\section{MATERIALS AND M ETHODS}

This work has entailed four experiments, one in a greenhouse and three in the field.

The experiment in the greenhouse was carried out from $08 / 08$ to $11 / 18 / 2014$, in the Experimental Fields Section of Embrapa Vegetables, Brasilia - DF. 
The experimental design was completely randomized in a factorial $4 \times 2 \times 3$, with four replications. Linuron herbicide in doses of $0,225,450$ and $675 \mathrm{~g}$ a.i. $\mathrm{h}^{-1}$ was sprayed on plants with 1 or 2-3 true leaves of cultivars Brasilia, Kuronan, and Verano. The commercial product used in the field experiments and greenhouse was Afalon ${ }^{\circledR} \mathrm{SC}$.

Each experimental unit consisted of a plastic vase with $21.0 \mathrm{~cm}, 23.0 \mathrm{~cm}$ diameter and a capacity of $5.0 \mathrm{dm}^{3}$ of soil. As substrate, it was used soil mixture, sand and plant compound at a ratio of 3: 1: 1,respectively, with $100 \mathrm{mg}$ of nitrogen, $200 \mathrm{mg}$ phosphorus and $150 \mathrm{mg}$ of potassium per kg of substrate. Twenty carrot seeds were homogeneously distributed on the soil surface and incorporated up to $2 \mathrm{~cm}$ depth. Subsequently, there was thinning, keeping up two plants per pot. At 30 and 50 days after sowing, plants were fertilized with nutrient solution, containing $100 \mathrm{mg}$ potassium per $\mathrm{kg}$ of soil at each season.

Each pot was placed on a plastic bottle of larger diameter and without holes, in order to maintain the water regime of the plots. Soil moisture was monitored daily, replenishing to water in bottles when necessary.

The herbicide was applied in 8/28/2014 (plants with 1 leaf) and 08/09/2014 (plants with 23 leaves), between 8:35am and 9:25am. Knapsack sprayer was used at constant pressure (maintained by $\mathrm{CO}_{2}$ ) of $2.8 \mathrm{kgf} \mathrm{cm}^{-2}$, equipped with bar with two flat spray tips TTI 110015 spaced at $0.5 \mathrm{~m}$, with tail consumption equivalent to $200 \mathrm{~L} \mathrm{ha}^{-1}$. At the moment of application 35-41\% relative humidity was recorded, 22.0 to $25.8{ }^{\circ} \mathrm{C}$ of air temperature, 18.9 the $24.1{ }^{\circ} \mathrm{C}$ soil temperature ( $5 \mathrm{~cm}$ deep), there was no wind, the sky was cloudless and the ground was wet.

The visual symptoms of phytointoxication were assessed at $7,15,21$ and 28 days after application (DAA) of the herbicide, through the scale scores from 0 to $100 \%$, where 0 represents no visual damage and 100 death of the plant (SBCPD, 1995).

At 102 days after sowing, the plants were removed from the vessel and separated into aerial and root parts. The roots were weighed and had their length and diameter measured. Shoot height and fresh weight were also determined.

In the field, two experiments with cultivar Verano (11/18/2014 to 03/18/2015) were employed and another with cv. BRS Planalto (07/06 to 10/20/2015), in the area of commercial carrot production in the municipality of Cristalina - GO.

The altitude of the locations is $1.002,1.004$ and 989 meters, latitude $16^{\circ} 08^{\prime} 57.5^{\prime \prime} \mathrm{S}$,

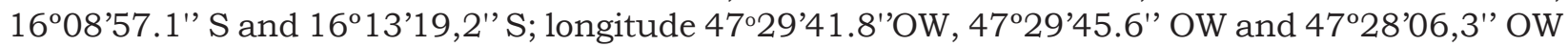
for the experiments with Verano (first and second) and BRS Planalto, respectively. According to the Köppen classification, the climate is Aw - tropical humid, with dry winter (Cardoso et al, 2014.). The soil of the experimental area is representative of this region and is classified as Red Latosol, clay texture class (in experiments with Verano) and heavy clay (in the experiment with BRS Planalto), with organic matter $3.5,3.3$ and $2.8 \mathrm{dag} \mathrm{kg}^{-1}$, respectively, for the experiments with Verano (first and second) and BRS Planalto.

In the three experiments, the experimental design was a randomized block in factorial $2 \times 5$, with four replications. Carrot plants, at two development stages ( 1 and 3 true leaves for Verano, 1 and 2 true leaves for BRS Planalto), were sprayed with the herbicide linuron in five doses $(0$, 225, 450, 675 and $990 \mathrm{~g}$ a.i. ha ${ }^{-1}$ ).

The carrot cultivars were chosen as a function of possible genetic differences among them. Verano is a hybrid popularly used in the summer. Brasilia, BRS Planalto and Kuronan are cultivars of open pollination, and BRS Planalto derived directly from the Brasilia cultivar, which has been a role model in summer carrot production in Brazil; and Kuronan results from the crossing of Nantes and Kuroda.

To avoid possible interference in culture all the plots were kept with no weeds up to the harvest of carrot, with hand removal of any "leaks" of chemical control and hand removal of all weeds in the treatment with no herbicide (zero dose).

The carrot was grown in beds with $1.4 \mathrm{~m}$ wide and $0.4 \mathrm{~m}$ between beds. Sowing was mechanical (seeder Stanhay brand, model Star) with the distribution of seeds in three triple lines (two lateral and one central), $0.1 \mathrm{~m}$ wide each, spaced at $0.4 \mathrm{~m}$. The base fertilizations consisted of applying 
2,000 kg ha-1 formulated 03-35-06. At 35, 45, 60 and 75 days after sowing were carried out fertilization in coverage, using each time $57 \mathrm{~kg} \mathrm{ha}^{-1} \mathrm{~K}_{2} \mathrm{O}$ in the form of potassium chloride.

In experiments with Verano, the plots were $1.4 \mathrm{~m}$ wide (three triple lines) and $4.0 \mathrm{~m}$ long, with a central triple line $\left(0.5 \mathrm{~m}\right.$ wide) and $2.0 \mathrm{~m}$ in length as floor area totaling $1.0 \mathrm{~m}^{2}$. To BRS Planalto, the plots presented $1.4 \mathrm{~m}$ wide (three triple lines) and $2.0 \mathrm{~m}$ in length with the three triple lines (1.4 m wide) by $1.0 \mathrm{~m}$ length of the useful area $\left(1.4 \mathrm{~m}^{2}\right)$.

In the field we adopted the same herbicide application technology described for the experiment in a greenhouse, except for the bar, which was composed of three flat spray tips TTI 110015, spaced $0.5 \mathrm{~m}$. Table 1 shows the development stage of carrot plants, day, time, and the soil and weather conditions at the time of application.

Table 1 - Number of leafs of carrot plants, date, time and soil and weather conditions at the time of herbicide applications in the field experiments

\begin{tabular}{|c|c|c|c|c|c|c|c|c|c|c|}
\hline \multirow{2}{*}{\multicolumn{2}{|c|}{ Experiment }} & \multirow{2}{*}{$\begin{array}{l}\text { Number } \\
\text { of leaves }\end{array}$} & \multirow[t]{2}{*}{ Date } & \multirow[t]{2}{*}{ Schedule } & \multicolumn{2}{|c|}{$\begin{array}{c}\text { Temperature } \\
\left({ }^{\circ} \mathrm{C}\right)\end{array}$} & \multirow{2}{*}{$\begin{array}{l}\text { Relative } \\
\text { humidity } \\
(\%)\end{array}$} & \multirow{2}{*}{$\begin{array}{l}\text { Wind } \\
\text { speed } \\
\left(\mathrm{km} \mathrm{h}^{-1)}\right.\end{array}$} & \multirow{2}{*}{$\begin{array}{l}\text { Nebulo } \\
\text { sity (\%) }\end{array}$} & \multirow{2}{*}{$\begin{array}{c}\text { Soil } \\
\text { moisture }\end{array}$} \\
\hline & & & & & Air & Ground & & & & \\
\hline \multirow{4}{*}{ Verano } & \multirow{2}{*}{1} & 1 & 05/Dec/2014 & $9 \mathrm{~h} 50-10 \mathrm{~h} 05$ & 25.7 & 26.5 & 66 & 2.0 & 10 & wet \\
\hline & & 3 & 12/Dec/2014 & $9 \mathrm{~h} 20-9 \mathrm{~h} 40$ & 25.5 & 23.5 & 77 & 1.5 & 0 & wet \\
\hline & \multirow{2}{*}{2} & 1 & 05/Dec/2014 & 10h10-10h25 & 26.5 & 26.5 & 66 & 4.5 & 10 & wet \\
\hline & & 3 & 12/Dec/2014 & $9 \mathrm{~h} 45-10 \mathrm{~h} 00$ & 26.8 & 25.5 & 70 & 4.0 & 0 & wet \\
\hline \multirow{2}{*}{\multicolumn{2}{|c|}{ BRS Planalto }} & 1 & $30 / \mathrm{Jul} / 2015$ & $8 \mathrm{~h} 35-9 \mathrm{~h} 00$ & 20.4 & 15.5 & 60 & 8.1 & 0 & wet \\
\hline & & 2 & 06/Aug/2015 & $8 \mathrm{~h} 15-8 \mathrm{~h} 30$ & 20.6 & 14.5 & 55 & 5.1 & 0 & wet \\
\hline
\end{tabular}

Possible visual injuries in carrot plants were evaluated at 15, 30 and 45 DAA herbicide, using a scale from 0 to $100 \%$, where 0 represents the absence of visual injuries and 100 death of the plant (SBCPD 1995 ).

Harvest was done manually, removing all the roots of the useful area of the portions, which were separated in commercial and disposal, counted and weighed to obtain the quantity and root fresh weight per plot. The values were estimated for ton ha $\mathrm{h}^{-1}$ and a thousand un. ha- ${ }^{-1}$, respectively for productivity and amount of commercial roots, disposal and total (commercial + disposal). For commercial productivity were recorded only roots perfect (no deformation, green shoulder, cracks and free from insect attack) that had length greater than $12 \mathrm{~cm}$ and a diameter greater than $2.5 \mathrm{~cm}$; the remaining roots were classified as waste.

Based on the productivity data and quantity of commercial roots and discard per plot, it determined the fresh weight of root and discard commercial root per plant. The fresh weight of the aerial part of 10 plants $(\mathrm{kg})$, length and diameter ten roots $\left(\mathrm{cm}\right.$ and $\mathrm{mm} \mathrm{root}^{-1}$, respectively) were also evaluated.

Data from each experiment (greenhouse or field) were submitted to the $F$ test analysis of variance. The effects of treatments and their interaction, when significant, were compared by Tukey test at $5 \%$ probability or polynomial fit of the data.

\section{RESULTS AND DISCUSSION}

In the greenhouse, linuron herbicide did not cause visual injury to carrot plants of the three tested cultivars. Consequently, the growth was not affected by the treatments studied, except the length of the roots, which differed among cultivars (Table 2). The roots of hybrid Verano had greater length $(14.31 \mathrm{~cm})$ than the roots of cultivars Brasilia $(11.73 \mathrm{~cm})$ and Kuronan $(12.69 \mathrm{~cm})$. However, these results were not dependent on linuron dosage or time of application. It is then natural differences between genotypes studied. In addition, isolated and interaction of these treatments did not significantly change any other measured characteristic. 
Table 2 - F test results of analysis of variance for fresh weight, length and diameter of root and fresh weight, and height of shoot of three carrot cultivars treated at two time periods (plants 1 and 2-3 leaves) with four doses of linuron

\begin{tabular}{|c|c|c|c|c|c|}
\hline \multirow{2}{*}{ Sources of variation } & \multicolumn{3}{|c|}{ Root } & \multicolumn{2}{|c|}{ Shoot } \\
\hline & Fresh weight & Length & Diameter & Fresh weight & Height \\
\hline Dosage & $1.47^{\mathrm{ns}}$ & $0.54^{\mathrm{ns}}$ & $2.80^{\mathrm{ns}}$ & $421.61^{\mathrm{ns}}$ & $0.18^{\mathrm{ns}}$ \\
\hline Time & $0.30^{\mathrm{ns}}$ & $0.04^{\mathrm{ns}}$ & $0.36^{\mathrm{ns}}$ & $1.49^{\mathrm{ns}}$ & $0.18^{\mathrm{ns}}$ \\
\hline Cultivar & $0.37^{\mathrm{ns}}$ & $8.57 * *$ & $2.34^{\mathrm{ns}}$ & $0.64^{\mathrm{ns}}$ & $0.16^{\mathrm{ns}}$ \\
\hline linuron $\mathrm{x}$ time & $0.48^{\mathrm{ns}}$ & $1.66^{\mathrm{ns}}$ & $0.92^{\mathrm{ns}}$ & $206.80^{\mathrm{ns}}$ & $2.75^{\mathrm{ns}}$ \\
\hline linuron $\mathrm{x}$ cultivar & $1.66^{\mathrm{ns}}$ & $0.58^{\mathrm{ns}}$ & $1.83^{\mathrm{ns}}$ & $289.53^{\mathrm{ns}}$ & $1.88^{\mathrm{ns}}$ \\
\hline Time $\mathrm{x}$ cultivar & $2.09^{\mathrm{ns}}$ & $0.31^{\mathrm{ns}}$ & $2.36^{\mathrm{ns}}$ & $518.23^{\mathrm{ns}}$ & $1.88^{\mathrm{ns}}$ \\
\hline Lin. $x$ p. $x$ cultivar & $2.13^{\mathrm{ns}}$ & $1.11^{\mathrm{ns}}$ & $1.97^{\mathrm{ns}}$ & $687.84^{\mathrm{ns}}$ & $1.08^{\mathrm{ns}}$ \\
\hline VC $(\%)$ & 33.55 & 19.50 & 20.71 & 32.94 & $11.11^{\mathrm{ns}}$ \\
\hline \multirow{2}{*}{ Overall average } & (g per plant) & $(\mathrm{cm})$ & $(\mathrm{mm})$ & (g per plant) & $(\mathrm{cm})$ \\
\hline & 72.46 & 12.91 & 27.53 & 39.97 & 47.74 \\
\hline
\end{tabular}

** Significant at $1 \%$ probability for $\mathrm{F}$ test. ${ }^{\text {ns }}$ No significant by $\mathrm{F}$ test.

Corroborating these data in the field, linuron herbicide sprayed regardless of dosage (up to $990 \mathrm{~g}$ a.i. ha ${ }^{-1}$ ) and plant development stage, not caused visual phytotoxicity the carrot of both cultivars studied. The same was observed in another study with the application of 140 and $280 \mathrm{~g}$ a.i. ha ${ }^{-1}$ of linuron in carrot plants cv. Sativa 'Mark I' (Bellinder et al., 1997). Linuron $\left(1,100 \mathrm{~g}\right.$ a.i. ha $\left.{ }^{-1}\right)$, sprayed post-emergence also caused no visible damage to carrot plants $\mathrm{cv}$. Cosmos (Williams II and Boydston, 2005). These results are substantiated by the crop selectivity mechanism to the herbicide that is by metabolization of the product in plants by means of demetoxilação and demethylation of the molecule reactions, inactivating it a non toxic form (Pascal-Lorber et al. 2010; Rodrigues and Almeida, 2011).

No significant effects of the individual treatments and their interaction in the evaluated characteristics (Tables 3, 4, 5, 6, 7 and 8), except for the second experiment Verano, wherein the interaction time $\mathrm{x}$ dose was significant for the amount of roots of disposal and total (commercial + discard). In this experiment, when the carrot plants have three true leaves at the time of application, there was no significant difference between linuron dosages for quantity disposal roots and total (Figure 1).

For plants with a sheet, the number of roots of disposal and total increased linearly with the increase of the dosage of the herbicide. Each $225 \mathrm{~g}$ a.i. ha-1 was increased linuron 32 thousand disposal of roots per hectare higher than the control ( 0 dosage), reflecting the total amount of roots, which increased by 36 thousand units ha- ${ }^{-1}$. The increase in the amount of discharge of roots did not influence the amount of commercial roots, which remained constant, even increasing the dose of linuron. The herbicide did not affect the productivity disposal roots. This demonstrates that the fresh mass by disposing carrot plant decreases with the increase of the quantity per area, does not justify the significance of linuron dosages for disposal of carrot productivity.

Table 3 - Test results $\mathrm{F}$ analysis of variance for produ tivity and quantity of commercial roots, disposal and total (commercial + discard) of carrot cv. Verano, depending on the dosage and time of application of the herbicide linuron - $1^{\text {st }}$ experiment

\begin{tabular}{|l|c|c|c|c|c|c|}
\hline \multirow{2}{*}{ Source of variation } & \multicolumn{3}{|c|}{ Produc tivity roots } & \multicolumn{3}{c|}{ Quantity roots } \\
\cline { 2 - 7 } & Commercial & Discard & Total & Commercial & Discard & Total \\
\hline Time & $0.01^{\mathrm{ns}}$ & $0.19^{\mathrm{ns}}$ & $0.13^{\mathrm{ns}}$ & $0.16^{\mathrm{ns}}$ & $0.15^{\mathrm{ns}}$ & $0.03^{\mathrm{ns}}$ \\
\hline Dosage & $0.36^{\mathrm{ns}}$ & $0.58^{\mathrm{ns}}$ & $0.39^{\mathrm{ns}}$ & $0.37^{\mathrm{ns}}$ & $0.41^{\mathrm{ns}}$ & $0.42^{\mathrm{ns}}$ \\
\hline Time $\mathrm{x}$ dosage & $0.70^{\mathrm{ns}}$ & $1.25^{\mathrm{ns}}$ & $0.41^{\mathrm{ns}}$ & $1.53^{\mathrm{ns}}$ & $0.95^{\mathrm{ns}}$ & $1.64^{\mathrm{ns}}$ \\
\hline VC $(\%)$ & 14.56 & 19.20 & $9.62^{-1}$ & 13.74 & 23.64 & 13.67 \\
\hline \multirow{2}{*}{ Overall average } & \multicolumn{3}{|c|}{ (ton ha $\left.^{-1}\right)$} & \multicolumn{4}{|c|}{ Thousand un. ha $\left.^{-1}\right)$} \\
\cline { 2 - 8 } & 41.41 & 21.57 & 62.98 & 320.21 & 367.08 & 687.29 \\
\hline
\end{tabular}

${ }^{\text {ns }}$ No significant the test F. 
Table 4 - F test results of variance analysis for fresh weight of commercial root and discard per plant, diameter and root length of carrot cv. Verano and fresh weight of shoots of ten plants of carrot cv. Verano, depending on the dosage and time of application of herbicide linuron - $1^{\text {st }}$ experiment

\begin{tabular}{|c|c|c|c|c|c|}
\hline \multirow{2}{*}{ Source of variation } & \multicolumn{2}{|c|}{ Fresh root mass per plant } & \multirow{2}{*}{ Root diameter } & \multirow{2}{*}{ Root length } & \multirow{2}{*}{$\begin{array}{l}\text { Weight fresh } \\
\text { shoot }\end{array}$} \\
\hline & Commercial & Discard & & & \\
\hline Time & $0.42^{\mathrm{ns}}$ & $1.05^{\mathrm{ns}}$ & $0.13^{\mathrm{ns}}$ & $0.29^{\mathrm{ns}}$ & $0.22^{\mathrm{ns}}$ \\
\hline Dosage & $0.72^{\mathrm{ns}}$ & $0.52^{\mathrm{ns}}$ & $0.06^{\mathrm{ns}}$ & $0.19^{\mathrm{ns}}$ & $0.45^{\mathrm{ns}}$ \\
\hline Time $\mathrm{x}$ dosage & $2.95^{\mathrm{ns}}$ & $0.52^{\mathrm{ns}}$ & $1.22^{\mathrm{ns}}$ & $1.91^{\mathrm{ns}}$ & $1.02^{\mathrm{ns}}$ \\
\hline $\mathrm{VC}(\%)$ & 8.46 & 20.97 & 8.32 & $8.25^{\mathrm{ns}}$ & 25.85 \\
\hline \multirow{2}{*}{ Overall average } & \multicolumn{2}{|c|}{ (g) } & $(\mathrm{mm})$ & $(\mathrm{cm})$ & $(\mathrm{kg})$ \\
\hline & 129.83 & 60.09 & 30.25 & 16.68 & 0.47 \\
\hline
\end{tabular}

${ }_{\text {ns }}$ No significant the test F.

Table 5 - F test results of analysis of variance for productivity and quantity of commercial roots, disposal and total (commercial + discard) of carrot $\mathrm{cv}$. Verano, depending on the dosage and the time of aplication of the herbicide linuron - $2^{\text {nd }}$ experiment

\begin{tabular}{|c|c|c|c|c|c|c|}
\hline \multirow{2}{*}{ Source of variation } & \multicolumn{3}{|c|}{ Productivity roots } & \multicolumn{3}{|c|}{ Quantity roots } \\
\hline & Commercial & Discard & Total & Commercial & Discard & Total \\
\hline Time & $0.11^{\mathrm{ns}}$ & $0.09^{\mathrm{ns}}$ & $0.46^{\mathrm{ns}}$ & $0.24^{\mathrm{ns}}$ & $0.06^{\mathrm{ns}}$ & $0.31^{\mathrm{ns}}$ \\
\hline Dosage & $0.84^{\mathrm{ns}}$ & $0.81^{\mathrm{ns}}$ & $0.42^{\mathrm{ns}}$ & $1.52^{\mathrm{ns}}$ & $1.76^{\mathrm{ns}}$ & $2.26^{\mathrm{ns}}$ \\
\hline Time $\mathrm{x}$ dosage & $0.43^{\mathrm{ns}}$ & $3.40^{\mathrm{ns}}$ & $1.43^{\mathrm{ns}}$ & $1.16^{\mathrm{ns}}$ & $2.99 *$ & $3.62 *$ \\
\hline $\mathrm{VC}(\%)$ & 13.36 & 18.85 & 7.16 & 10.53 & 17.54 & 8.44 \\
\hline \multirow{2}{*}{ Overall average } & \multicolumn{3}{|c|}{$\left(\right.$ ton $\left.\mathrm{ha}^{-1}\right)$} & \multicolumn{3}{|c|}{ (thousand un. ha ${ }^{-1}$ ) } \\
\hline & 42.92 & 20.51 & 63.44 & 333.54 & 368.75 & 702.29 \\
\hline
\end{tabular}

* Significant at $5 \%$ probability for the test F. ns No significant the test $\mathrm{F}$.

Table 6 - F test results of analysis of variance for fresh weight of commercial root and discard per plant, diameter and root length of carrot cv. Verano, depending on the dosage and time of application of the herbicide linuron - $2^{\text {nd }}$ experiment

\begin{tabular}{|c|c|c|c|c|}
\hline \multirow{2}{*}{ Source of variation } & \multicolumn{2}{|c|}{ Fresh root mass by plant } & \multirow{2}{*}{ Root diameter } & \multirow{2}{*}{ Root length } \\
\hline & Commercial & Discard & & \\
\hline Time & $0.90^{\mathrm{ns}}$ & $0.34^{\mathrm{ns}}$ & $3.32^{\mathrm{ns}}$ & $4.32^{\mathrm{ns}}$ \\
\hline Dosage & $1.01^{\mathrm{ns}}$ & $1.33^{\mathrm{ns}}$ & $0.63^{\mathrm{ns}}$ & $2.23^{\mathrm{ns}}$ \\
\hline Time $\mathrm{x}$ dosage & $1.37^{\mathrm{ns}}$ & $0.66^{\mathrm{ns}}$ & $0.66^{\mathrm{ns}}$ & $0.76^{\mathrm{ns}}$ \\
\hline $\mathrm{VC}(\%)$ & 8.11 & 13.49 & 5.71 & 7.42 \\
\hline \multirow{2}{*}{ Overall average } & \multicolumn{2}{|c|}{$(\mathrm{g})$} & $(\mathrm{mm})$ & $(\mathrm{cm})$ \\
\hline & 128.86 & 56.10 & 30.40 & 17.64 \\
\hline
\end{tabular}

${ }^{\text {ns }}$ No significant the test $\mathrm{F}$.

Table 7 - F test results of analysis of variance for productivity and quantity of commercial roots, disposal and total (commercial + discard) of carrot cv. BRS Planalto, depending on the dosage and time of application of the herbicide linuron

\begin{tabular}{|c|c|c|c|c|c|c|}
\hline \multirow{2}{*}{ Source of variation } & \multicolumn{3}{|c|}{ Productivity roots } & \multicolumn{3}{|c|}{ Quantity roots } \\
\hline & Commercial & Discard & Total & Commercial & Discard & Total \\
\hline Time & $0.09^{\mathrm{ns}}$ & $1.52^{\mathrm{ns}}$ & $0.02^{\mathrm{ns}}$ & $0.73^{\mathrm{ns}}$ & $0.48^{\mathrm{ns}}$ & $1.54^{\mathrm{ns}}$ \\
\hline Dosage & $0.21^{\mathrm{ns}}$ & $0.92^{\mathrm{ns}}$ & $0.05^{\mathrm{ns}}$ & $1.39^{\mathrm{ns}}$ & $0.75^{\mathrm{ns}}$ & $0.57^{\mathrm{ns}}$ \\
\hline Time $\mathrm{x}$ dosage & $1.08^{\mathrm{ns}}$ & $1.32^{\mathrm{ns}}$ & $1.44^{\mathrm{ns}}$ & $1.33^{\mathrm{ns}}$ & $1.64^{\mathrm{ns}}$ & $3.31^{\mathrm{ns}}$ \\
\hline $\mathrm{VC}(\%)$ & 22.64 & 13.59 & 16.14 & 17.04 & 17.58 & 10.54 \\
\hline \multirow{2}{*}{ Overall average } & \multicolumn{3}{|c|}{$\left(\right.$ ton ha $\left.^{-1}\right)$} & \multicolumn{3}{|c|}{ (thousand un. ha $^{-1}$ ) } \\
\hline & 30.09 & 19.46 & 49.54 & 258.75 & 438.47 & 697.22 \\
\hline
\end{tabular}

ns No significant by F test. 
Table 8 - F test results of fresh weight for analysis of variance commercial root and disposal of plant, diameter and cv carrot root length BRS Planalto and fresh weight of shoot ten plants, depending on the dosage and time of application of herbicide linuron

\begin{tabular}{|c|c|c|c|c|c|}
\hline \multirow{2}{*}{ Source of variation } & \multicolumn{2}{|c|}{ Fresh root mass per plant } & \multirow{2}{*}{ Root diameter } & \multirow{2}{*}{ Root Length } & \multirow{2}{*}{$\begin{array}{c}\text { Shoot fresh } \\
\text { weight }\end{array}$} \\
\hline & Commercial & Discard & & & \\
\hline Time & $0.61^{\mathrm{ns}}$ & $2.84^{\mathrm{ns}}$ & $0.05^{\mathrm{ns}}$ & $0.18^{\mathrm{ns}}$ & $0.06^{\mathrm{ns}}$ \\
\hline Dosage & $1.36^{\mathrm{ns}}$ & $0.61^{\mathrm{ns}}$ & $0.59^{\mathrm{ns}}$ & $1.03^{\mathrm{ns}}$ & $1.51^{\mathrm{ns}}$ \\
\hline Time $\mathrm{x}$ dosage & $0.74^{\mathrm{ns}}$ & $0.48^{\mathrm{ns}}$ & $0.39^{\mathrm{nsns}}$ & $0.14^{\mathrm{ns}}$ & $1.69^{\mathrm{ns}}$ \\
\hline $\mathrm{VC}(\%)$ & 14.24 & 19.57 & 8.88 & 6.37 & 25.24 \\
\hline \multirow{2}{*}{ Overall average } & \multicolumn{2}{|c|}{$(\mathrm{g})$} & $(\mathrm{mm})$ & $(\mathrm{cm})$ & $(\mathrm{kg})$ \\
\hline & 116.25 & 45.83 & 27.62 & 15.44 & 0.39 \\
\hline
\end{tabular}

ns No significant by F Test.
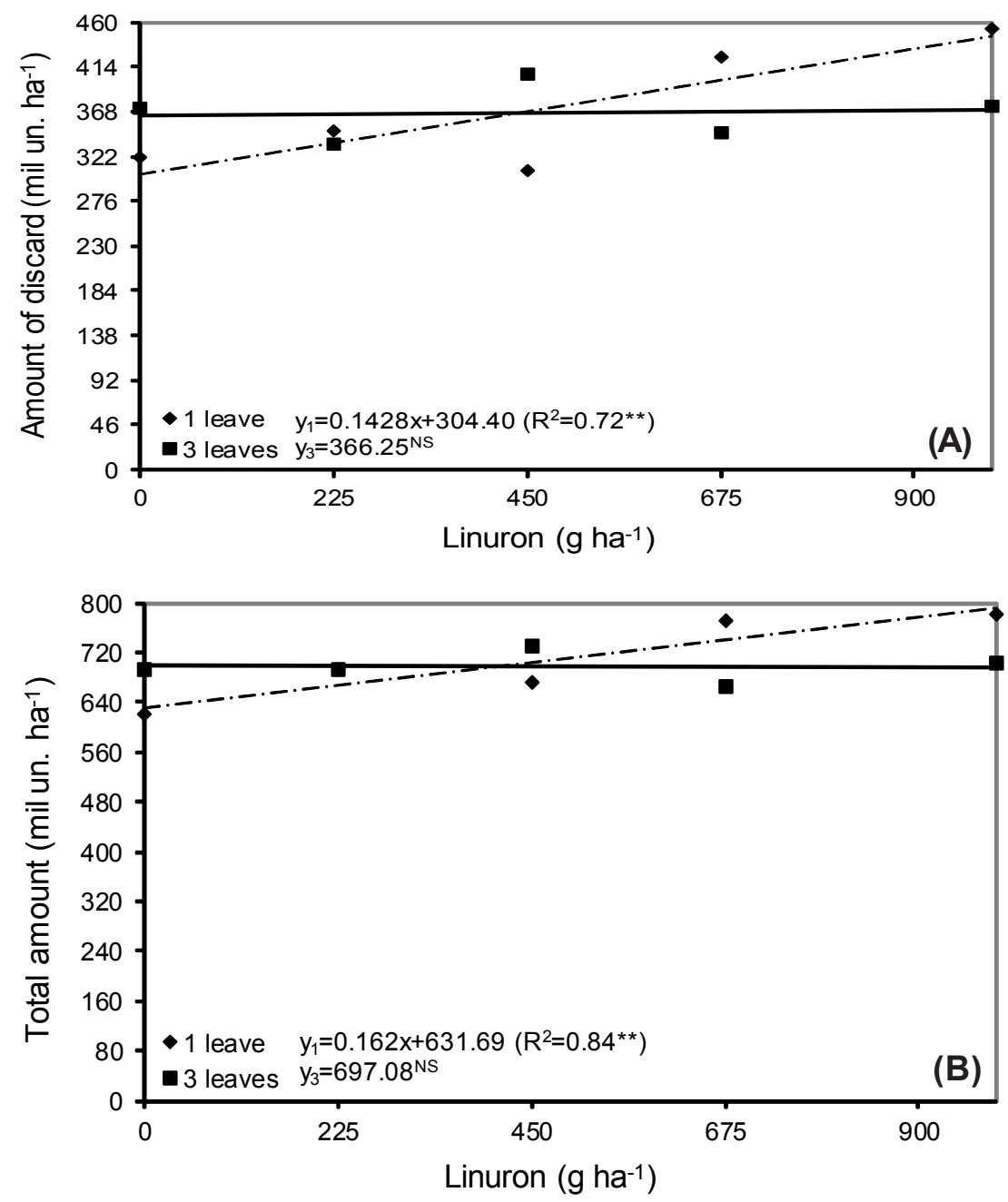

Figure 1 - Amount of discard roots (A) and total (B) (commercial + discard) of carrot cv. Verano sprayed with linuron, at doses of $0,225,450,675$ and $990 \mathrm{~g}$ a.i. ha ${ }^{-1}$, when plants had one or three leaves - $2^{\text {nd }}$ experiment.

The hypothesis that the linuron herbicide in doses recorded for culture, does not affect the development of carrot plants was confirmed by this study, which proved that the linuron was selective for the cultivars Verano and BRS Planalto in dosages of up to $990 \mathrm{~g} \mathrm{ha}^{-1}$. Other studies have also demonstrated the selectivity of linuron for growing carrots, sprayed post-emergence, even at higher dosages than $990 \mathrm{~g} \mathrm{ha}^{-1}$, and 1,186 g a.i. ha-1 for cultivar Neptune (Main et al., 2013) and 2,250 g a.i. ha-1 for cultivars Dominator and Caro-Choice (Jensen et al., 2004). 
Based on these results, it was found that the linuron herbicide sprayed post-emergence, was selective for growing carrots, regardless of cultivar, product dosage and plant development stage at the time of application.

\section{ACKNOWLEDGMENTS}

We would like to thank Agrícola Wehrmann, on behalf of Agronomist Luciano Brito, HF manager, who has made the areas for installation of field experiments available.

\section{REFERENCES}

Anuário Brasileiro de Hortaliças. Anuário Brasileiro de Hortaliças 2015. Santa Cruz do Sul: Gazeta, 2015. p.37-8.

Alterman M.K., Jones A.P. Herbicidas: Fundamentos fisiológicos y bioquímicos del modo de acción. Santiago do Chile: Ediciones Universidad Católica del Chile, 2003.333p.

Alvarez J.M., Hutchinson P.J.S. Managing hairy nightshade to reduce potato viruses and insect vectors. Outlooks Pest Manage J. 2005;16:249-52.

Bellinder R.R., Kirkwyland J.J., Wallace R.W. Carrot (Daucus carota) and weed response to linuron and metribuzin applied at different crop stages. Weed Technol. 1997;11:235-40.

Boydston R.A., Mojtahedi H., Crosslin J.M. Effect of hairy nightshade (Solanum sarrachoides) presence on potato nematode, disease, and insect pests. Weed Sci. 2008;56:151-4.

Cardoso M.R., Marcuzzo F.F., Barros J.R. Classificação climática de Köppen-Geiger para o estado de Goiás e Distrito Federal. Acta Geogr. 2014;8:40-55.

Coelho M., Bianco S., Carvalho L.B. Interferência de plantas daninhas na cultura da cenoura (Daucus carota). Planta Daninha. 2009;27:913-20.

Freitas F.C.L. et al. Periods of weed interference in carrot in function of spacing between rows. Planta Daninha. 2009;27:473-80.

Gruszecki R. et al. Effect of living mulch and linuron on weeds and yield of carrot under ridge cultivation. Acta Sci Pol Hortorum Cultus. 2015;14:67-82.

Jensen K.I.N., Doohan D.J., Specht E.G. Response of processing carrot to metribuzin on mineral soils in Nova Scotia. Can J Plant Sci. 2004;84:669-76.

Main D.C. et al. Comparison of synthetic and organic herbicides applied banded for weed control in carrots (Daucus carota L.). Can J Plant Sci. 2013;93:857-61.

Pacanoski Z., Týr S., Veres T. Effects of herbicides and their combinations in carrots production regions in the republic of Macedonia. Herbologia. 2014;14:47-60.

Pascal-Lorber S. et al. Metabolic fate of $\left[{ }^{14} \mathrm{C}\right]$ Diuron and $\left[{ }^{14} \mathrm{C}\right]$ linuron in wheat (Triticum aestivum) and radish (Raphanus sativus). J Agric Food Chem. 2010;58:10935-44.

Rodrigues B.N., Almeida F.L.S. Guia de herbicidas. $6^{a}$ ed. Londrina: Edição dos autores, 2011. 697p.

Sociedade Brasileira da Ciência das Plantas Daninhas - SBCPD. Procedimentos para instalação, avaliação e análise de experimentos com herbicidas. Londrina: 1995. 42p.

Swanton C.J., O’Sullivan J., Robinson D.E. The critical weed-free period in carrot. Weed Sci. 2010;58:229-33.

Williams II M.M., Boydston R.A. Alternative to hand-weeding volunteer potato (Solanum tuberosum) in carrot (Daucus carota). Weed Technol. 2005;19:1050-5.

Zagonel J., Reghin M.Y., Venâncio W.S. Controle pós-emergente de plantas daninhas em cenoura. Hortic Bras. 1999;17:69-71. 